\title{
Pengaruh Zeolit Sintetis Terhadap Stabilitas dan Sensitivitas Biosensor Asam Urat Berbasis Lactobacillus Plantarum Menggunakan Metode Voltametri Siklik
}

\author{
Faizah*, Dwi Puryanti, Afdhal Muttaqin \\ Laboratorium Fisika Material, Jurusan Fisika \\ Fakultas Matematika dan Ilmu Pengetahuan Alam Universitas Andalas \\ Kampus Unand Limau Manis, Padang, 25163 Indonesia \\ *izafaizah84@gmail.com
}

\begin{abstract}
ABSTRAK
Pembuatan material biosensor termodifikasi zeolit sintetis telah dilakukan untuk mendeteksi asam urat. Penelitian ini bertujuan untuk melihat pengaruh zeolit sintetis pada material biosensor asam urat terhadap stabilitas dan sensitivitas sensor. Penggunaan biosensor untuk mengukur asam urat menggunakan urikase yang dihasilkan dari bakteri Lactobacillus plantarum. Pemodifikasian material biosensor menggunakan zeolit sintetis kandungan Sodalit yang ditambahkan dalam campuran grafit dan paraffin. Elektroda pasta karbon (EPK) dibuat dengan komposisi grafit: paraffin sebesar $70 \mathrm{mg}$ : $30 \mathrm{mg}$, sedangkan elektroda pasta karbon termodifikasi zeolit (EPKZ) dengan komposisi grafit: paraffin: zeolit sebesar $50 \mathrm{mg}$ : $30 \mathrm{mg}: 20$ mg. Didalam masing-masing elektroda diteteskan 7,5 $\mu$ l pelet L.plantarum (EPKZLP). Pengujian kinerja elektroda dilakukan menggunakan Voltametri Siklik. Hasil pemodifikasian mempengaruhi performa biosensor seperti sensitivitas, dan stabilitas. Arus tertinggi dihasilkan oleh EPKZLP dengan rentang arus 0,0143 - 0,0592 mA. Sensitivitas terbaik dihasilkan pada EPKZLP dengan nilai sebesar 0,031 $\mathrm{mAcm}^{-}$ ${ }^{2} \mathrm{mM}^{-1}$. Kestabilan terbaik didapatkan pada EPKZLP dengan presentase kestabilan pada hari ke-14 sebesar 30,9 \%. Standar deviasi rata-rata yang dihasilkan pada penelitian ini $0.0024 \mathrm{~mA}$ dengan nilai kesalahan relatif masing-masing sebesar $7,8 \%$.

Kata-kata kunci: biosensor asam urat, zeolit, sodalit, sensitivitas, stabilitas.
\end{abstract}

\begin{abstract}
The synthesis of synthetic zeolite modified biosensor material has been carried out to detect uric acid. This study aims to look at the effect of synthetic zeolite on uric acid biosensor material on sensor stability and sensitivity. The biosensor was use to measure uric acid using uricase produced Lactobacillus plantarum. Modification of biosensor material using synthetic zeolite content of Sodalit is added in a mixture of graphite and paraffin. Carbon paste electrode (EPK) was made with graphite and paraffin comparison $70 \mathrm{mg}: 30 \mathrm{mg}$, while zeolite modified carbon paste electrode (EPKZ) with graphite, paraffin and zeolite comparison $50 \mathrm{mg}$ : $30 \mathrm{mg}$ : $20 \mathrm{mg}$. In each electrode, $7.5 \mu \mathrm{l}$ of L.plantarum pellet (EPKZLP) was dropped. Electrode performance testing was carried out using Cyclic Voltammetry. Modification results affect biosensor performance such as sensitivity and stability. The highest current is produced by EPKZLP with a current range of $0.0143-0.0592 \mathrm{~mA}$. The best sensitivity is produced in EPKZLP with a value of $0.031 \mathrm{mAcm}^{-2} \mathrm{mM}^{-1}$. The best stability was found in EPKZLP with a percentage of stability on day 14 was $30.9 \%$. The average standard deviation generated in this study is $0.0024 \mathrm{~mA}$ with a relative error value was $7.8 \%$. Keywords: uric acid biosensor, zeolite, sodalit, sensitivity, stability.
\end{abstract}

\section{PENDAHULUAN}

Zeolit sintetis banyak digunakan sebagai adsorben, katalis dan penukar ion. Hal ini dikarenakan zeolit sintetis memiliki tingkat kemurnian yang lebih tinggi serta keseragaman ukuran pori bila dibanding zeolit alam (Sugiarti, dkk., 2016). Struktur zeolit yang berpori membuat zeolit banyak dimanfaatkan diberbagai bidang, salah satunya yaitu sebagai sensor. Nanda dkk (2018) telah membuat material sensor termodifikasi zeolit sintetis untuk mendeteksi glukosa. Kamal (2014) juga membuat material biosensor termodifikasi zeolit alam untuk mendeteksi asam urat. Pada penelitian ini akan dibuat material biosensor termodifikasi zeolit sintetis untuk mendeteksi asam urat.

Asam urat itu sendiri merupakan produk akhir metabolisme purin dalam tubuh. Kelebihan atau kekurangan kadar asam urat dalam darah sering menjadi indikasi adanya berbagai penyakit pada tubuh manusia. Gangguan kesehatan itu berupa gout arthritis akut, pembentukan tofus, gagal ginjal dan lain-lain. Kadar asam urat dalam darah normal pada lakilaki yaitu 3-7,2 mg/dl sedangkan pada perempuan yaitu 2-6 mg/dl (Putra, 2006). 
Kadar asam urat di dalam tubuh perlu diukur secara akurat dan cepat agar penyakit asam urat dapat dideteksi sejak dini sehingga tidak menimbulkan berbagai macam penyakit. Salah satu metode yang banyak digunakan adalah metode spektrofotometri (Mateo, dkk., 2007). Metode ini mulai dialihkan, karena kurang spesifik, sangat peka terhadap cahaya dan tidak ekonomis. Seiring berjalannya waktu banyak peneliti menggunakan biosensor yaitu perangkat analisis yang menggabungkan komponen biologis dengan detektor fisikokimia (Arslan, 2008). Biosensor memiliki banyak kelebihan yaitu sensitivitas tinggi, kecepatan waktu analisis dan efisiensi biaya.

Biosensor didasarkan pada enzim urikase. L. plantarum merupakan mikroba penghasil enzim urikase yang diketahui memiliki aktivitas yang baik terhadap asam urat (Diana, 2016). Enzim bebas bersifat tidak stabil sehingga harus diimobilisasi. Zeolit merupakan salah satu material yang dapat digunakan untuk media imobilisasi enzim karena strukturnya yang berpori (Mardiah, dkk., 2009).

Biosensor terdiri atas dua komponen utama yaitu bioreseptor dan transduser. Bioreseptor adalah molekul yang akan mengenali analit target. Interaksi spesifik antara analit target dan tempat pengenalan analit pada bioreseptor akan menghasilkan perubahan kimia-fisika yang kemudian akan dideteksi dan diukur oleh transduser.

Proses pendeteksian pada biosensor seperti ditunjukkan pada Gambar 1 bermula dari larutan uji yang memiliki elemen pengenal terhadap transduser. Pada penelitian ini transduser yang digunakan berupa elektroda pasta karbon yang dimodifikasi dengan zeolit/L.plantarum. Elemen asam urat yang terdeteksi akan terikat spesifik sedangkan yang lain akan terpisah. Elektroda yang telah dimodifikasi akan mentransfer sinyal kimia dari reaksi pada larutan dan selanjutnya akan berubah menjadi sinyal listrik (Tribidasari dan Ivandini, 2006). Sinyal listrik akan dikonversi menjadi ukuran pembacaan kadar asam urat pada larutan.

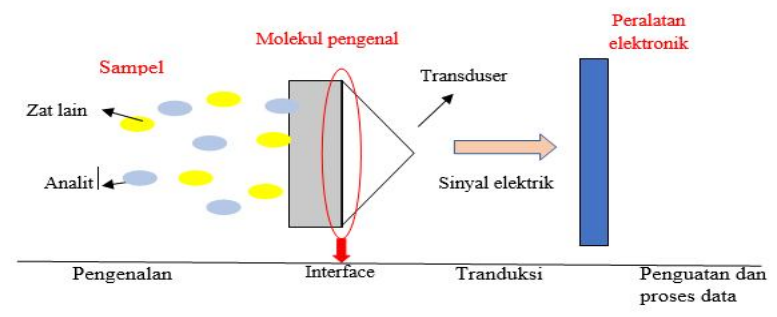

Gambar 1 Ilustrasi pendeteksian pada sensor (Sumber:Istiqomah, 2008)

Ketika ke dalam sel pengukuran ditambahkan larutan asam urat, sel L. plantarum akan mensekresikan enzim urikase sehingga akan terjadi reaksi pemecahan purin pada struktur asam urat menghasilkan produk alantoin dan hidrogen peroksida. Hidrogen peroksida tersebut yang akan mengalami reaksi redoks. Reaksi redoks ini akan menghasilkan elektron yang akan berinteraksi dengan transduser. Reaksi tersebut dapat dilihat pada Gambar 2.

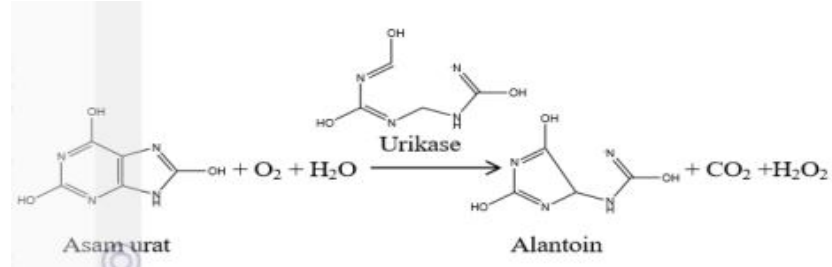

Gambar 2 Mekanisme reaksi asam urat dengan enzim urikase

(Sumber:Lestari, 2016)

$$
\mathrm{H}_{2} \mathrm{O}_{2} \leftrightarrow \mathrm{O}_{2}+2 \mathrm{H}^{+}+2 \mathrm{e}
$$

Pemanfaatan zeolit pada biosensor asam urat berfungsi sebagai molekul pengenal yang terintegrasi pada elektroda agar menghasilkan arus saat proses pendeteksian asam urat. Struktur zeolit pada Gambar 3 terbentuk oleh tetrahedral $\left[\mathrm{SiO}_{4}\right]^{-4}$ dan $\left[\mathrm{AlO}_{4}\right]^{-5}$ yang saling terhubung 
oleh atom-atom oksigen sehingga membentuk rongga-rongga. Molekul ataupun ion akan masuk ke dalam rongga/pori zeolit. Sifat ini juga yang mendasari penggunaan zeolit sebagai media imobilisasi enzim (Xing, dkk., 2000). Zeolit sintetis yang digunakan pada penelitian ini merupakan zeolit hasil penelitian Nurhabibah dan Muttaqin (2017) dengan kemurnian 100\% didalamnya terkandung zeolit jenis sodalit yang dibuat dari bahan limbah abu dasar batubara menggunakan metode peleburan alkali hidrotermal dengan waktu peleburan selama 2 jam.

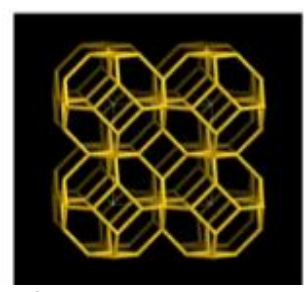

Gambar 3 Framework zeolit sodalit

(Sumber: Database of zeolite structure, 2007)

\section{METODE}

Penumbuhan bakteri L. plantarum dilakukan di Laboratorium Teknologi Hasil Ternak, Fakultas Peternakan, Universitas Andalas. Untuk melakukan pengukuran CV perlu dilakukan beberapa persiapan diantaranya, pembuatan elektroda pembanding $\mathrm{Ag} / \mathrm{AgCl}$, pembuatan elektroda pasta karbon (EPK/EPKZ), dan elektroda pendukung yang berasal dari buatan pabrik. Pengujian karakteristik elektroda dilakukan di Laboratorium Fisika Material, Jurusan Fisika, Fakultas Matematika dan Ilmu Pengetahuan Alam, Universitas Andalas.

\subsection{Penumbuhan dan Pemanenan L.plantarum}

Sebanyak $5 \mathrm{ml}$ media $M R S$ Broth cair dipipet ke dalam tabung reaksi. Sebanyak 1 ose bakteri L. plantarum murni ditanam ke media MRS Broth cair tersebut dan diinkubasi pada suhu $37{ }^{\circ} \mathrm{C}$ selama 24 jam. Setelah 24 jam, sebanyak $5 \mathrm{ml}$ larutan MRS Broth cair yang sudah ditumbuhi $L$. plantarum dipipet ke tabung sentrifugasi dan diputar pada kecepatan $10.000 \mathrm{rpm}$ selama 10 menit. Setelah itu, pelet dicuci 2 kali dengan akuades steril dan disentrifus pada kecepatan $10.000 \mathrm{rpm}$ selama 5 menit. Pelet $L$. plantarum yang sudah bersih diberi larutan fisiologis $(\mathrm{NaCl} 0.85 \%)$ sebanyak $1 \mathrm{ml}$.

\subsection{Pembuatan elektroda pembanding $\mathrm{Ag} / \mathrm{AgCl}$}

Pembuatan elekroda $\mathrm{Ag} / \mathrm{AgCl}$ menggunakan 2 buah kawat perak sepanjang masingmasing $7 \mathrm{~cm}$. Kawat dililit dengan tembaga sebagai penghantar arus. Selanjutnya, dilakukan pelapisan dengan metode elektrokimia menggunakan $50 \mathrm{ml}$ larutan $\mathrm{KCl} 1 \mathrm{M}$ yang diberi tegangan 1,5 V. Waktu pelapisan berlangsung 1,5 menit dan akan menghasilkan endapan hitam pada perak.

\subsection{Pembuatan elektroda kerja EPK dan EPKZ}

Bahan yang digunakan untuk pembuatan elektroda kerja adalah grafit $70 \mathrm{mg}$ dan paraffin $30 \mathrm{mg}$ untuk jenis EPK+LP. Sedangkan untuk EPKZ+LP perbandingan komposisi bahan yaitu grafit $50 \mathrm{mg}$, paraffin $30 \mathrm{mg}$, dan zeolit $20 \mathrm{mg}$. Adapun kandungan fraksi zeolit dalam persentase pada tiap jenisnya ditunjukkan dalam Tabel 2. Seluruh bahan dicampur dalam wadah dan diletakkan di atas magnetic stirrer bersuhu $60^{\circ} \mathrm{C}$. Bahan yang telah homogen dimasukkan setinggi $0,5 \mathrm{~cm}$ pada bagian bawah tabung kaca berdiameter $0,3 \mathrm{~cm}$. Kawat tembaga sebagai penghubung elektroda, dimasukkan ke dalam tabung agar dapat menempel pada bahan. Sebanyak 7,5 $\mu 1$ pelet $L$. plantarum diteteskan pada permukaan elektroda pasta karbon yang telah dibuat tanpa maupun dengan penambahan zeolit.

\subsection{Karakterisasi menggunakan Voltametri Siklik}

Kinerja sensor diuji menggunakan metode Voltametri Siklik dengan melakukan input tegangan dalam program Echem sehingga akan menghasilkan arus terbaca. Ketiga elektroda 
disusun dalam gelas piala seperti pada Gambar 3 dan kemudian wadah diisi larutan asam urat konsentrasi 0,1-0,5 mM. Hasil pendeteksian menghasilkan grafik voltammogram yang berarti siklus oksidasi dan reduksi larutan telah berlangsung. Nilai maksimal dan data yang diambil sebagai pembacaan adalah nilai arus puncak oksidasi pada voltammogram.

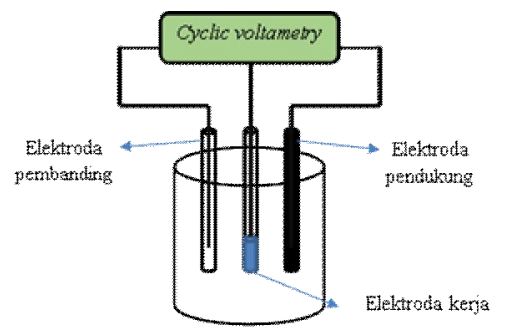

Gambar 4 Skema pengukuran elektrokimia sistem 3 elektroda

(Sumber: Nanda dkk, 2018)

\section{HASIL DAN DISKUSI}

Gambar 5 menampilkan perbedaan pembacaan dari tiga larutan. Perbedaan pembacaan pada tiga larutan tersebut ditunjukkan dengan kemunculan puncak arus yang menandai terjadinya proses oksidasi. Proses oksidasi ternyata hanya terjadi pada larutan asam urat yang ditambahkan dengan larutan blanko buffer borat, dan tidak terlihat pada larutan lainnya. Kehadiran larutan buffer borat dapat membantu mempertahankan $\mathrm{pH}$ larutan yang akan diuji agar tetap pada keadaan asam. Ini menunjukkan bahwa enzim urikase bekerja pada keadaan asam. Hal ini terjadi karena enzim yang dihasilkan dari bakteri L.plantarum dapat menjadi tidak aktif atau rusak apabila berada pada kondisi $\mathrm{pH}$ yang jauh berbeda dari $\mathrm{pH}$ optimal.

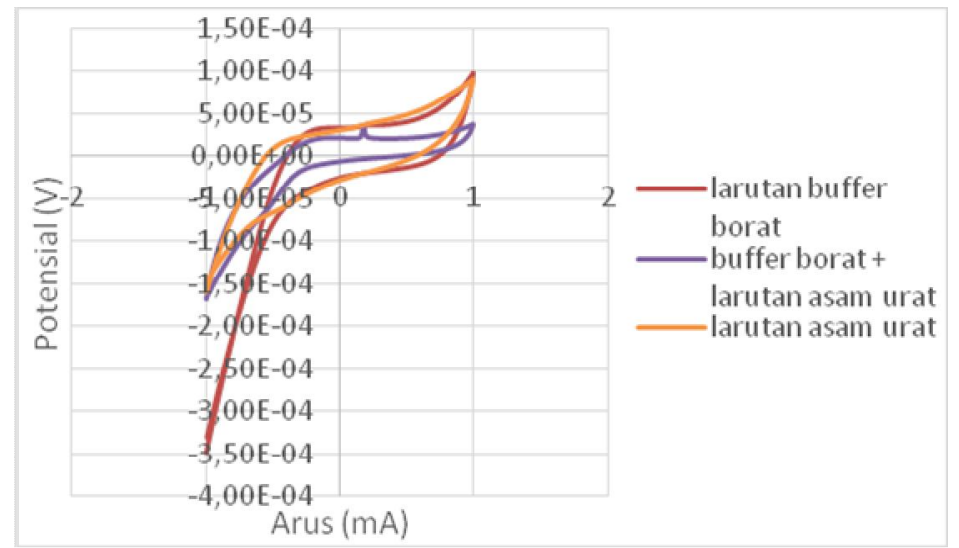

Gambar 5 Voltammogram arus oksidasi larutan asam urat, buffer borat, dan buffer borat + larutan asam urat

Karakterisasi dengan voltametri siklik pada material biosensor tanpa dimodifikasi dengan zeolit (EPKLP) dan material biosensor termodifikasi zeolit (EPKZLP), keduanya menghasilkan puncak arus anodik yang menandakan terjadinya proses oksidasi. Pengukuran dilakukan dengan variasi konsentrasi larutan asam urat 0,$1 ; 0,2 ; 0,3 ; 0,4$ dan $0,5 \mathrm{mM}$. Voltamogram dari kedua material biosensor tersebut dapat dilihat pada Gambar 6. Pada Gambar 6 puncak arus oksidasi EPKLP dihasilkan pada rentang potensial 0,224-0,354 V, sedangkan puncak arus oksidasi EPKZLP dihasilkan pada rentang potensial 0,166 - 0,240 V. Kecilnya potensial yang dihasilkan dari pengukuran pada EPKZLP menunjukkan bahwa untuk mendeteksi sebuah larutan uji hanya dibutuhkan sedikit energi. Begitu pula pada waktu responnya, waktu respon yang menunjukkan terbentuknya proses oksidasi pada EPKZLP juga lebih cepat dibanding waktu respon yang dihasilkan EPKLP (Tabel 1). Hal ini menunjukkan bahwa penggunaan material biosensor termodifikasi zeolit (EPKZLP) lebih efektif dalam mendeteksi larutan uji. 


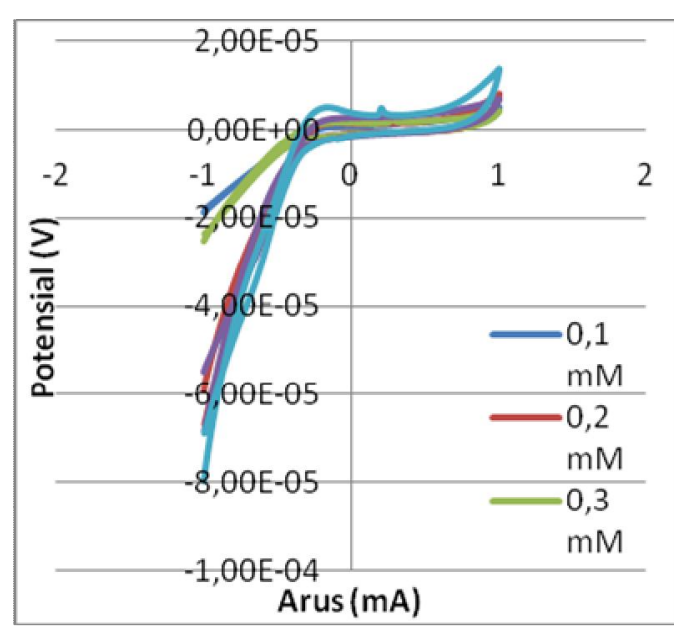

(a)

Arus (mA)

Gambar 6 Voltamogram (a) EPKLP dan

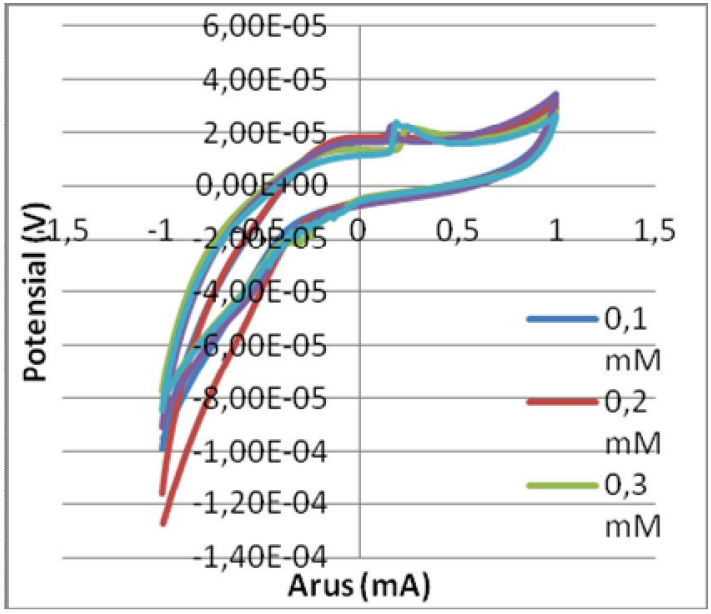

(b) EPKZLP

Tabel 1 Potensial puncak oksidasi, respon arus dan waktu respon pada EPKLP dan EPKZLP

\begin{tabular}{ccccccc}
\hline \multirow{2}{*}{$\begin{array}{c}\text { Konsentrasi } \\
(\mathbf{m M})\end{array}$} & $\begin{array}{c}\text { Arus Puncak } \\
\text { Oksidasi (mA) }\end{array}$ & $\begin{array}{c}\text { Potensial } \\
(\mathbf{V})\end{array}$ & $\begin{array}{c}\text { Waktu } \\
\text { Respon (s) }\end{array}$ & $\begin{array}{c}\text { Arus Puncak } \\
\text { Oksidasi (mA) }\end{array}$ & $\begin{array}{c}\text { Potensial } \\
(\mathbf{V})\end{array}$ & $\begin{array}{c}\text { Waktu } \\
\text { Respon (s) }\end{array}$ \\
\hline 0.1 & 0.0019 & 0.352 & 13.52 & 0.0190 & 0.216 & 12.16 \\
0.2 & 0.0021 & 0.354 & 13.54 & 0.0204 & 0.172 & 11.72 \\
0.3 & 0.0026 & 0.278 & 12.78 & 0.0227 & 0.240 & 12.40 \\
0.4 & 0.0037 & 0.224 & 12.24 & 0.0229 & 0.166 & 11.66 \\
0.5 & 0.0048 & 0.250 & 12.50 & 0.0239 & 0.188 & 11.88 \\
\hline
\end{tabular}

Variasi konsentrasi larutan asam urat dilakukan untuk mengamati kerja elektroda terhadap perubahan konsentrasi yang diberikan seperti ditunukkan pada Gambar 7. Respon arus yang dihasilkan dari pengukuran menggunakan material biosensor tanpa dimodifikasi dengan zeolit (EPKLP) memiliki nilai yang lebih rendah dibanding material biosensor setelah dimodifikasi dengan zeolit (EPKZLP). Respon arus tertinggi dihasilkan dari pengukuran menggunakan material biosensor yang dimodifikasi dengan zeolit (EPKZLP). Respon EPKZLP ini salah satunya berkaitan dengan penambahan zeolit sebagai bahan pemodifikasian pada material biosensor. Struktur dan sifat zeolit yang berpori menyebabkan zeolit dapat bertindak sebagai adsorben pada pengimobilisasiannya terhadap L.plantarum. Selain itu, peningkatan konsentrasi larutan juga menyebabkan banyaknya ion yang terurai sehingga arus semakin meningkat. Arus yang terbaca dalam pengukuran pada material biosensor setelah dimodifikasi dengan zeolit mengalami peningkatan sebesar $121 \%$ dari arus pada pembacaan menggunakan elektroda tanpa dimodifikasi zeolit.

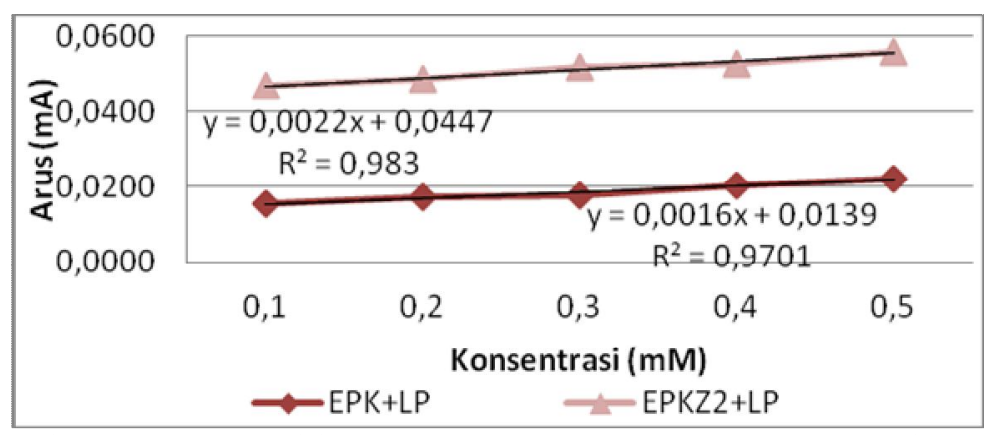

Gambar 7 Perbandingan konsentrasi larutan asam urat terhadap arus terdeteksi pada EPKLP dan EPKZLP 
Nilai pembacaan pada Gambar 7 menunjukkan bahwa setiap elektroda memiliki sensitivitas yang berbeda sebagai respon terhadap nilai konsentrasi larutan asam yang diukur. Hal tersebut ditunjukkan dengan besarnya nilai slope yang menyebabkan perubahan arus yang besar sehingga sensitivitas elektroda dikatakan baik jika nilai slope kurva tinggi (Miller dan Miller, 1988). Pada Gambar 7 dapat dilihat bahwa nilai slope kurva yang dihasilkan EPKZLP lebih besar dibanding EPKLP, sehingga sensitivitas yang dihasilkan juga semakin baik. EPKZLP menghasilkan nilai sensitivitas sebesar $0,031 \mathrm{mAcm}^{-2} \mathrm{mM}^{-1}$, sedangkan sensitivitas yang dihasilkan EPKLP sebesar $0,023 \mathrm{mAcm}^{-2} \mathrm{mM}^{-1}$.

Keberulangan dari material biosensor yang dibuat pada penelitian ini telah dicoba. Data pada Gambar 7 merupakan sampel pembacaan arus yang dihasilkan dari material biosensor baik sebelum dimodifikasi dengan zeolit maupun setelah dimodifikasi dengan zeolit yang dilakukan dalam tiga kali pengukuran pada tiap konsentrasinya. Pengukuran tersebut menghasilkan nilai standar deviasi masing-masing elektroda yaitu sebesar 0,0014 mA dan 0,0031 mA. Sedangkan standar deviasi relatif atau kesalahan relatif yang dihasilkan dalam pengukuran pada EPKLP dan EPKZLP masing-masing sebesar 7,7\% dan 7,8\%.

Selain itu pengukuran stabilitas diperlukan untuk melihat berapa lama material biosensor tersebut dapat digunakan. Pada Gambar 7 dapat dilihat bahwa material biosensor setelah dimodifikasi dengan zeolit Z2 (EPKZLP) menunjukan daya tahan material yang lebih lama yaitu hingga 14 hari dibandingkan dengan tanpa dimodifikasi dengan zeolit (EPKLP) yang hanya mampu bertahan hingga 6 hari. Material biosensor tanpa dimodifikasi dengan zeolit (EPKLP) pada hari ke-6 kestabilannya telah menurun hingga 15,7\%. Sedangkan pada material biosensor lain yang telah dimodifikasi dengan zeolit (EPKZLP) kestabilannya terus menurun hingga hari ke-14 dengan persentase sisa kestabilan sebesar 30,9\%.

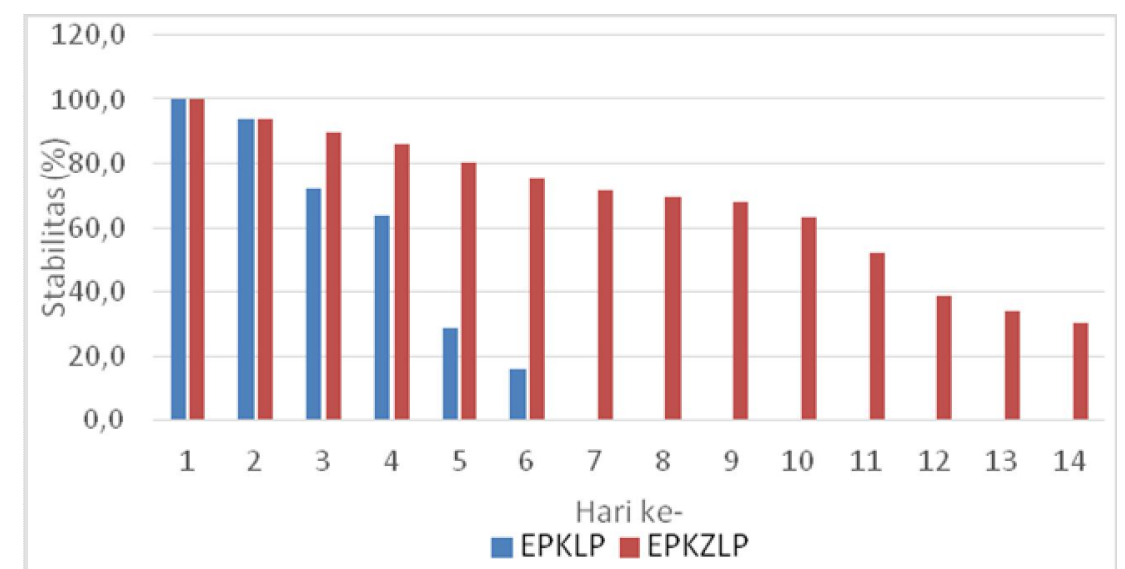

Gambar 8 Kurva stabilitas elektroda (EPK+LP dan EPKZ2+LP) pada konsentrasi 0,5 mM

\section{KESIMPULAN}

Berdasarkan hasil dan pembahasan dapat disimpulkan, material biosensor yang dihasilkan pada penelitian ini telah mampu mengenali larutan uji yang menandakan terbentuknya puncak arus oksidasi. Penambahan zeolit pada material biosensor berhasil meningkatkan kemampuan elektroda dalam membaca arus dibuktikan dengan semakin tinggi arus yang dihasilkan saat material biosensor tersebut dimodifikasi dengan zeolit. Arus tertinggi dihasilkan dari material biosensor termodifikasi zeolit (EPKZLP) dengan rentang arus 0,0143 mA - 0,0592 mA. Sedangkan sensitivitas tertinggi dihasilkan pada EPKZLP yaitu sebesar 0,031 $\mathrm{mAcm}^{-2} \mathrm{mM}^{-1}$. Penambahan zeolit pada material biosensor juga meningkatkan daya tahan material yang lebih lama hingga 14 hari dibandingkan dengan tanpa dimodifikasi yang hanya bertahan selama 6 hari. Kestabilan terbaik didapatkan pada EPKZ2+LP dengan presentase sisa kestabilan pada hari ke-14 sebesar 30,9\%. Nilai kesalahan relatif dari pengukuran-pengukuran pada elektroda-elektroda yang telah dilakukan rata-rata dibawah $20 \%$ dimana itu merupakan syarat minimum sebuah sensor. Hal ini membuktikan bahwa material biosensor yang dihasilkan pada penelitian ini telah memenuhi beberapa kriteria untuk dijadikan sebuah sensor. 


\section{DAFTAR PUSTAKA}

Arslan, F., "An Amperometric Biosensor for Uric Acid Determination Prepared from Uricase Immobilized in Polyaniline-Polypyrrole Film", Sensors Articels, 8, 492-500, 2008.

Database of Zeolite Structures, "Framework Zeolite", asia.iza-structure.org., diakses pada 28 Maret 2018, 2007.

Diana, N.R., "Imobilisasi Urikase Dari L. plantarum pada Karboksimetilselulose-Gelatin-Zeolit untuk Meningkatkan Stabilitas Biosensor Asam Urat", Tesis, Institut Pertanian Bogor, Bogor (2016).

Istiqomah, "Modifikasi Elektroda Karbon dengan Zeolit dan Aplikasinya sebagai Sensor Arsen (III)", Tesis, Ilmu Kimia Universitas Indonesia, Depok (2008).

Kamal, F., "Penentuan Kestabilan dan Linearitas Pada Biosensor Asam Urat Menggunakan Urikase dari L. plantarum Termodifikasi Zeolit Secara Elektrokimia", Skripsi, Fakultas Matematika dan Ilmu Pengetahuan Alam, Institut Pertanian Bogor, Bogor (2014).

Lestari, W., "Imobilisasi Sel L. plantarum Pada Membran Zeolit/Kappa-Karaginan untuk Meningkatkan Stabilitas Biosensor Asam Urat", Tesis, Fakultas Matematika dan Ilmu Pengetahuan Alam, Institut Pertanian Bogor, Bogor (2016).

Mardiah, E., Trivadila, Nurhidayat, N. dan Iswantini, D., "Aktivitas Urikase yang dihasilkan dari berbagai Sel Lactobaciilus Plantarum dan Parameter Kinetiknya", Jurnal Ilmu Pertanian Indonesia, 14, 163-169, 2009.

Mateo, C., Palomo, J.M., Lorente, G.F., Guisan, G.F.dan Lafuente, R.F., "Improvement Of Enzyme Activity, Stability, and Selectivity Via Immobilization Technique", Enzymitech, 40, 1451-1463, 2007.

Miller, J.C., dan Miller J. N., Statistic for Analytical Chemistry, $3^{\text {th }}$ edition, Ellis Horward Limited, New York (1988).

Nanda, F., Puryanti, D. dan Muttaqin, A., "Pengaruh Jenis Zeolit Terhadap Sensitivitas Material Sensor Non-Enzimatik Untuk Mendeteksi Glukosa", Jurnal Fisika Unand, 6, 394-399, 2018.

Nurhabibah dan Muttaqin, A., "Pengaruh Waktu Peleburan Terhadap Konduktivitas Listrik Zeolit Sintetis dari Abu dasar Batubara dengan Metode Peleburan Alkali Hidrotermal", Jurnal Fisika Unand, 6, 240-246, 2017.

Putra, T.R., Hiperurisemia, Reumatologi dalam Buku Ajar Ilmu Penyakit Dalam, Fakultas Kedokteran, Universitas Indonesia, Jakarta (2006).

Sugiarti, S., Charlena. dan Aflakhah, N.A., "Zeolit Sintetis Terfungsional 3-(Trimetoksisilil)-1Propantiol sebagai Adsorben Kation Cu(II) dan Biru Metilena", Jurnal Kimia Valensi, 3, 11-19, 2017.

Tribidasari, A. dan Ivandini, "Electrochemical Detection of Arsenic (III) Using IridiumImplanted Boron-Doped Diamond Electrodes”, Journal Analytical Chemistry, 78, 6291-6298, 2006.

Xing, G.W., Li, X.W., Tian, G.L.dan Ye, Y.H., "Enzymatic peptide synthesis in organic solvent with different zeolites as immobilization matrixes", Tetrahedron, 56, 3517-3522, 2000. 